\title{
Production Technology for Kopyor Coconut Seednuts and Seedlings in Indonesia
}

\author{
Hengky Novarianto ${ }^{1}$, Ismail Maskromo ${ }^{1,2}$, Dini Dinarti ${ }^{2}$, and Sudarsono ${ }^{2}$
}

\begin{abstract}
Kopyor coconut is a naturally-occurring mutant having fluffy solid endosperm in stead of the normal one. Similar type of coconut has been found in several other Asian countries, with their distinct local names, such as Macapuno (Philippines), Makhrao Kathi (Thailand), Dikiri Pol (Sri Lanka), Thairu Thengai (India). It is a delicacy coconut to Indonesian and sells as much as ten times higher than normal coconut. In nature, three types of kopyor coconut exist in Indonesia: kopyor tall, kopyor dwarf, and kopyor hybrid. There are three kopyor dwarf varieties ('Pati Kopyor Green Dwarf', 'Kopyor Yellow Dwarf' and 'Kopyor Brown Dwarf') officially released, and one registered tall variety ('Puan Kalianda Kopyor Tall'). In general, kopyor fruit yield under natural conditions is only $<25 \%$ of the total harvested fruits for both the tall and the dwarf types. Traditionally, Indonesian farmers harvest kopyor fruits at ten months after pollination while normal fruits at 11 months. They use the harvested normal fruits for propagation; but cannot guarantee whether or not they would produce korpyor fruit. Adoption of kopyor seedling production through embryo culture has been done. However, the seedling production is slow, while the price is very expensive, thus unaffordable to common farmers. Indonesian Palm Research Institute and Bogor Agricultural University have collaborated to develop alternative approaches to increase kopyor fruit production through the production of seedling that would ensure to produce korpyor fruit through control pollination. Initiated since 2010, the activities successfully overcome uncertainty in kopyor seedling production. Moreover, hybridization among local superior coconut varieties and known kopyor one have been done to broaden genetic background of kopyor trait and to develop breeding population for new kopyor varieties in the future. Overview and update of research progress on korpyor in Indonesia are presented in this paper.
\end{abstract}

Keywords: Coconut mutant, abnormal endosperm, controlled pollination, breeding population.

\footnotetext{
${ }^{1}$ Coconut Breeders at the Indonesian Palm Research Institute (IPRI), Manado, Indonesia. Email: hengkynovarianto@yahoo.com; is_maskromo@yahoo.com

${ }^{2}$ Lecturer and Research Scientist at PMB Lab., Department of Agronomy and Horticulture, Faculty of Agriculture, Bogor Agricultural University (IPB), Bogor, Indonesia.

Email: s_sudarsono@ymail.com
} 


\section{Introduction}

Korpyor, a type of curd coconut locally known in Indonesia and Malaysia, is a naturallyoccurring coconut mutant, found in several countries in Asia and the Pacific, such as the Philippines (Makapuno), Thailand (Maphrao Kathi), Sri Lanka (Dikiripol), India (Thairu Tengai), Vietnam (Dua Sap), Malaysia (Korpyor), Cambodia (Dong Kathi). This type of mutant is still rare and the price of kopyor fruits are relatively much higher than regular coconuts. The unique characteristics of kopyor fruits are fluffy and soft solid endosperm or meat (Figure 1). The gene controlling mutant kopyor character is a single recessive gene, designated as ' $k$ '. Kopyor fruit possesses a homozygote $k k$ embryos and a homozygote triploid $k k k$ endosperm. On the other hand, a normal coconut fruit may either possess a homozygote $K K$ embryo and triploid $K K K$ endosperm or, upon crossing with Korpyor, a heterozygote $K k$ embryo and triploid $K K k$ or $K k k$ endosperm.

The kopyor fruit (with $k k$ embryo and $k k k$ endosperm) will not germinate naturally since the endosperm cannot support normal development of the embryo. Consequently, the kopyor fruit is rotten and the embryo dies. The normal coconut fruit (with $K K$ zygotic embryo and $K K K$ endosperm) germinate into normal coconut seedling. However, such seedlings will never yield kopyor fruits. On the other hand, normal fruit (with $K k$ embryo and $K K k$ or $K k k$ endosperm) will germinate into normal coconut seedling and the palm still has a chance to yield kopyor fruits. These types of normal fruits are grown by regular farmers and sold as natural kopyor coconut seedlings. Since seedlings germinated from normal fruit with $K K$ embryos cannot be differentiated from those $K k$ ones, farmers selling the natural kopyor fruit seedlings cannot guarantee their seedlings. There is a 2:1 probability of getting the $K k$ kopyor coconut seedlings to the normal $K K$ ones.

The curd coconut in the Philippines (known as Makapuno) is generally a tall type (Ubaldo, et al., 2003). On the other hand, kopyor coconut in Indonesia exists naturally as either dwarf, tall, and hybrid types. Three kopyor dwarf varieties, have been officially released in Indonesia. They are 'Kopyor Green Dwarf' (KGD), 'Kopyor Yellow Dwarf' (KYD) and 'Kopyor Brown Dwarf' (KBD) (Novarianto, 2013). Kopyor fruit is very popular in major cities in Indonesia, such as: Jakarta, Bandung, Semarang and Surabaya. Consumers value the unique taste, aroma and texture of the fruit and use them for fresh consumption, or putting it in icecream or mixing with ice. The limited number of kopyor fruits availability drives the price of this fruit 5 to 10 times higher than the regular or the tender young coconut. Currently, the price of kopyor fruits at the farm gate ranges from US \$ 2,0-4,0 per fruit, depending on the fruit size and season.
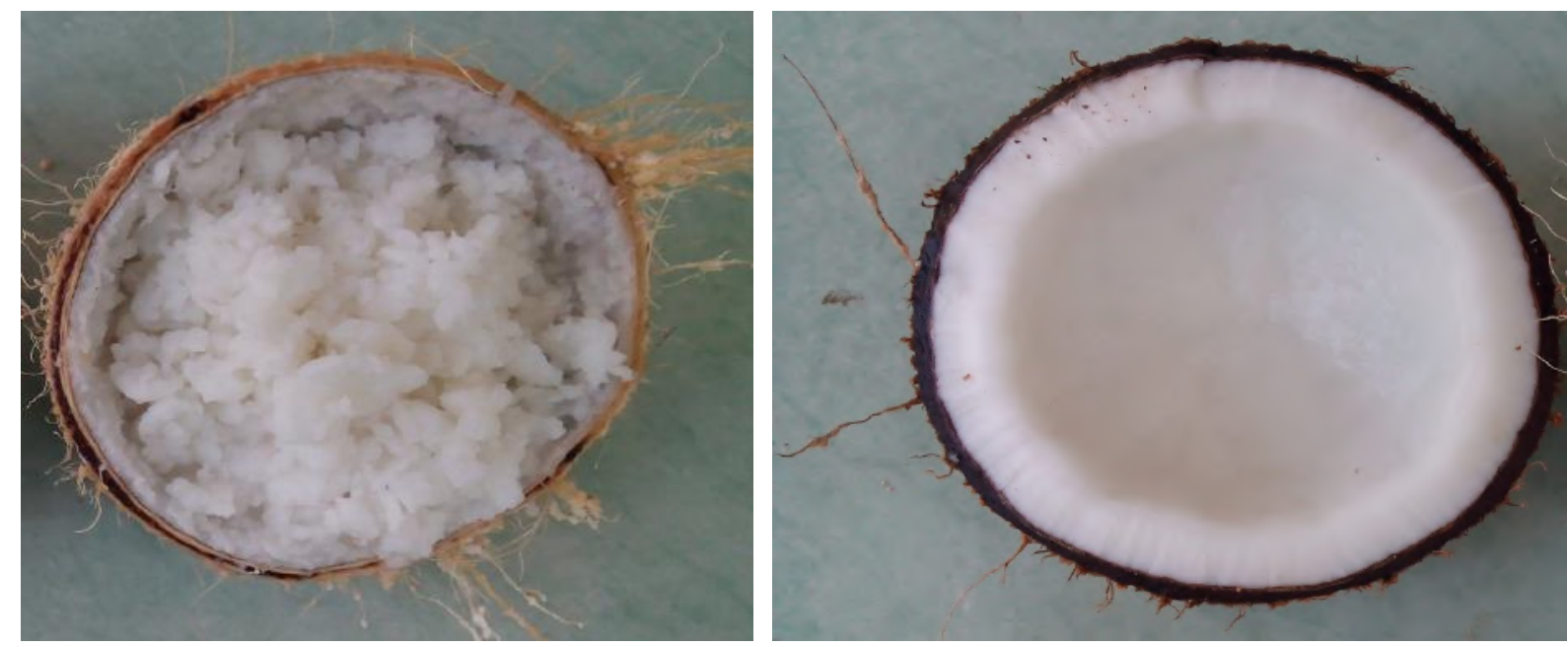

Figure 1. Comparison of endosperm character between kopyor and normal coconut. Left: endosperm of kopyor coconut is soft and fluffy. Right: on the other hand, endosperm of normal coconut is hard (right) 
Kopyor in Indonesia are mostly found in East Java (Akuba, et al., 2002), Central Java (Novarianto and Miftahorrachman, 2000), and Lampung (Mahmud, 2000). In East Java and Lampung, kopyor plants are mostly of the tall type. In Central Java, however, a mixture of dwarf, tall, and their hybrids are commonly exist in the field. Since the kopyor provenances are often grown as a mix culture with normal ones, the provenances are yielding low number of kopyor fruits (1-3 nuts per bunch). Under such condition, bunches yielding zero kopyor fruit are also quite common. Therefore, most of the harvested fruits are normal coconut.

At the regular farmer level, total nut yield harvested from kopyor tall type is approximately 30-60 nuts/palm/year while that of kopyor dwarf one are 50-100 nuts/palm/year. Among those, only $<25 \%$ (tall type) and $<40 \%$ (dwarf type) are kopyor fruits. Kopyor tall palm produces a range of 1-6 fruits/bunch and kopyor dwarf palm produces a range of 6-12 fruits/bunch (Maskromo et al., 2011). The calculated percentage of kopyor fruit production observed among three kopyor dwarf coconut varieties in the field, ranged from 24.8-38.9\% (Maskromo, et al., 2013). The ranges of kopyor to total nut yield ratios exhibited by individual palm may presumably be because of the differences in pollination behaviour between the two coconut types. Kopyor tall coconut tend to be mostly cross-pollinated, while kopyor dwarf ones tend to be self-pollinated. Therefore, testing the effects of open pollination and controlled pollination on kopyor fruits yield need some evaluations.

Homozygote $k k$ kopyor coconut seedlings derived from embryo cultures has proven to produce $100 \%$ kopyor fruits. However, the cost of such seedlings is too high for Indonesian farmers. Commercially, such seedling derived from embryo culture costs about US $\$ 50$ per seedling for kopyor tall type and US \$ 100 per seedling for kopyor dwarf type. Moreover, because the cultures are relatively slow growing, the consumer must fill pre-order and wait for approximately two years before the seedlings are ready for planting in the field. There is also a requirement to order for at least 100 seedlings in one pre-order. The reasons for expensive prices of such kopyor coconut seedlings are limited availability of kopyor zygotic embryos in the market as explant sources and possibly the less efficient embryo culture technique.

Therefore, regular kopyor coconut farmers cannot afford to buy such an expensive kopyor homozygote $k k$ seedlings, derived from zygotic embryo cultures. Only a resource intensive stake holders are able to buy such an expensive coconut seedlings. Therefore, there is a need to develop alternative solutions for producing trueto-type kopyor coconut seedlings, applicable at the regular kopyor coconut farmers. Hybridization among heterozygote $K k$ kopyor coconut own by regular farmers (as female) and homozygote $k k$ kopyor coconut produced from the embryos might be the alternative solution.

\section{Objectives}

(1) To evaluate the effects of controlled pollination on yield of kopyor fruits in Kopyor Dwarf Coconut.

(2) To evaluate method for increasing kopyor fruit yield traditionally at $25 \%$ kopyor fruits, to at least $50 \%$ by controlling hybridization between kopyor heterozygote $K k$ mother palms with kopyor homozygote $k k$ pollen donor. The kopyor homozygote $k k$ pollen donors are generated from embryo culture.

(3) To evaluate method for producing heterozygote $K k$ true-to-type $(100 \%$ of kopyor heterozygote $K k$ ) kopyor seedlings of either Dwarf, Tall, or Hybrid types. This method could potentially be used to replace traditional kopyor seedling production (a mixture of kopyor heterozygote $K k$ and normal homozygote $K K$ seedlings [2:1]) traditionally conducted by local farmers.

(4) To conduct hybridization between normal elite coconut varieties and kopyor coconut ones that can be used as breeding populations for future superior kopyor coconut variety development. 


\section{Application Targets}

(1) In the short term: Availability of techniques to increase kopyor coconut yield up to $25 \%$ through controlled pollination, applicable at the farmers level to support sustainable kopyor coconut production.

(2) In the medium term: Availability of techniques to increase kopyor coconut yield up to $50 \%$ through controlled hybridization among kopyor heterozygote $K k$ (grown by kopyor coconut farmers) with kopyor homozygote $k k$ (develop from embryo culture by IPRI and IPB).

(3) In the medium term: Availability of techniques to produce kopyor heterozygote $K k$ true-to-type seedlings (100\% kopyor heterozygote $K k$ at the local kopyor coconut seedling producers.

(4) In the long term: availability of breeding population that can be used to develop new-superior kopyor coconut varieties in the future.

\section{Research Approaches}

Since the year 2010-2014, under the cooperation of Indonesia Palm Research Institute (IPRI), Manado, and Bogor Agricultural University (IPB), Bogor, three-phases of research have been initiated. In the first phase (2010-2012), the effect of control pollination on kopyor fruit yield was tested. In the second phase (2012-2014), the effect of hybridization using homozygote $k k$ trees as donor pollens on kopyor fruit yield and kopyor heterozygote $K k$ seedlings production were evaluated. Finally, in the third phase (2013-2018), hybridization among kopyor coconut (Kk or $k k$ ) as mother plant and a number of normal elite coconut varieties $(K K)$ were initiated to establish large population of kopyor coconut breeding materials. The activities are conducted either in naturally growing kopyor coconut or in ex situ conservation location in Manado, North Sulawesi. The IPRI, Manado handles all the neccessary process for preparing pollens for all of the activities.

\section{Research Phase I (2010-2012)}

In this evaluation, kopyor mother palm were selected among mix provenances of dwarf, hybrid, and tall coconut, either capable of yielding kopyor fruit (genetically heterozygote $K k$ ) or only producing normal fruits (genetically homozygote $K K$ ). Three treatments were employed to the selected palms, namely: Treatment 1 - male flowers are partially emasculated and the inflorescences were covered with pollination bag. The female flowers were artificially pollinated using their own pollens; Treatment 2 - inflorescences were covered with pollination bag and self pollination was promoted naturally; and Treatment $3-$ inflorescences were left open for natural pollination (Figure 2). Kopyor fruits were harvested at 10 months after pollination while the normal ones were harvested at 11 months. Ten palms were selected for each treatment and three inflorescences were treated per palm. In this evaluation, a total of 30 sample palms and 90 inflorescences were observed.

\section{Research Phase II (2012-2014)}

In this evaluation, hybridization between heterozygote $K k$ kopyor coconut as mother plant with homozygote kk kopyor coconut as the pollen donor was conducted. The purpose of the hybridizations was to evaluate their effects on kopyor fruit yield and to produce heterozygote $K k$ kopyor coconut seedlings. The basic idea is that hybridization between a $K k$ female and a $\mathrm{kk}$ male parents will result in 50\% $k k$ and $50 \% \mathrm{Kk}$ progenies. Therefore, such hybridizations result in $50 \%$ of kopyor fruits and $50 \%$ of non-kopyor heterozygote $K k$ fruits. The non-kopyor heterozygote $K k$ can then be germinated to produce kk kopyor seedlings. The following are hybridization schemes:

(1) Hybridization between dwarf heterozygote $\mathrm{Kk}$ and dwarf homozygote $k k$ results in $50 \%$ kopyor dwarf heterozygote $K k$ and $50 \%$ dwarf homozygote $k k$;

(2) Hybridizations between dwarf heterozygote $K k$ and tall homozygote $k k$ results in 50\% hybrid homozygote $k k$ and $50 \%$ hybrid heterozygote $K k$; and 
(3) Hybridizations between tall heterozygote $K k$ and tall homozygote $k k$ results in $50 \%$ tall heterozygote $K k$ and $50 \%$ tall homozygote.

To facilitate such kopyor true-to-type seedlings, it is necessary to supply the kopyor coconut homozygote $k k$ derived from zygotic embryo culture as the pollen donor (male parent). The concurrent production of more kopyor coconut homozygote $\mathrm{kk}$ derived from zygotic embryo culture of dwarf and tall coconut types and hybridization to produce true-to-type seedlings have been implemented since 2012.
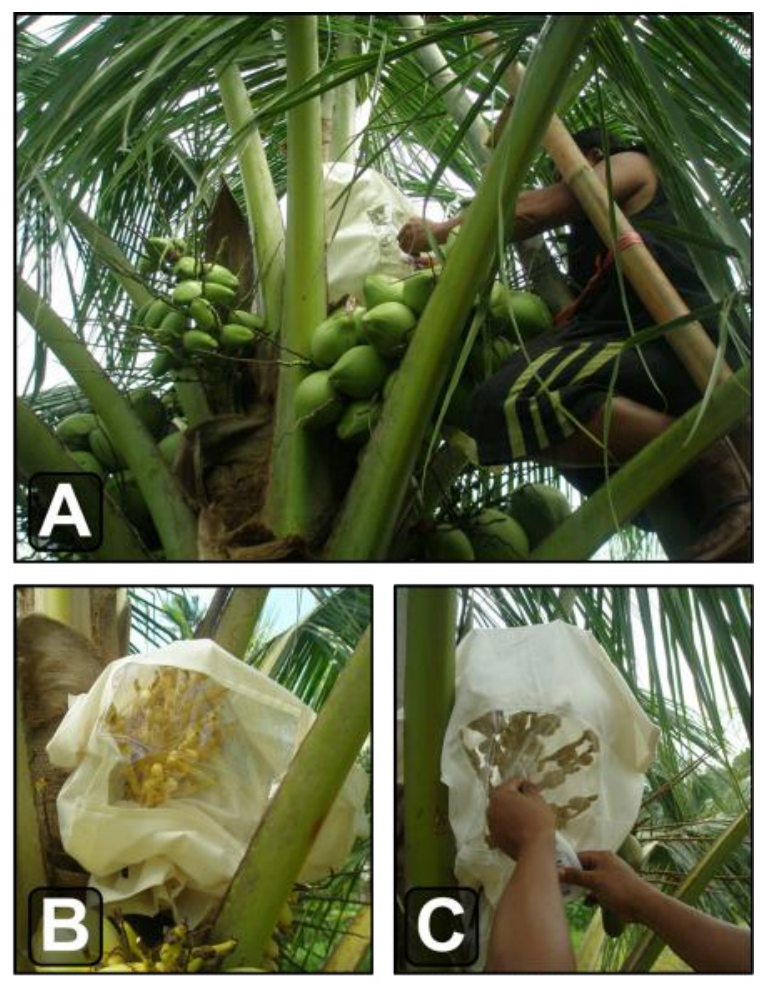

Figure 2. Treatments employed in the first phase of research. (A) Applying pollination bag to isolate the newly opened coconut inflorescense, (B) Isolated inflorescense ready for pollination, and (C) Artificial pollination on isolated inflorescence

\section{Research Phase III (2013-2018)}

The focus of this activity is to produce breeding population than can be used to broaden genetic base of kopyor coconut and develop superior kopyor coconut cultivars in the future.
Breeding population are the results of hybridization among normal elite coconuts having a number of desirable characters as male parents and the dwarf and tall types of kopyor coconut as the donor of kopyor character. The normal elite coconut used as pollen donor include: (1) Mapanget Tall (MTT) - as donor for thick and large quantity endosperm characters, (2) Bali Tall (BIT) - as donor for large fruit size character, (3) Takome Tall (TET) - as donor for high number of fruit per bunch character, and (4) Salak Green Dwarf (SGD) - as donor for superearly bearing character (start to bear fruits 2-3 years after planting). For the female parent, kopyor coconut from Central Java (dwarf type) and from Lampung (tall type) are selected.

Hybridizations have been initiated since 2013 and currently the seedlings are ready to harvest. The identity of the hybrids will be determined using standard molecular markers developed at IPB, Bogor. During and after the hybridization process, the rate of hybridization and germination success are evaluated.

\section{Preliminary Results}

\section{Research Phase I (2010-2012)}

Results of the control pollination effects on fruit setting (\%), total harvested fruits and kopyor fruit yield (\%) are presented in Table 1. The average number of female flowers per inflorescence was 17.5. Average fruit setting of $37.7 \%$ was the highest in treatment of open pollinated (Treatment 3). Bagging inflorescence with pollination bag, followed by natural self pollination (Treatment 2) resulted in second highest fruit setting $(29.27 \%)$ and bagging inflorescence followed by artificial selfpollination (Treatment 1) resulted in the lowest fruit setting $(23.05 \%)$. Similar response to the treatments was also observed for total number of harvested fruits. For the number of harvested fruits, Treatment 3 showed the highest (209 fruits), followed by Treatment 2 (144 fruits) and Treatment 1 (124 fruits).

Moreover, Treatment 3 also resulted in the highest (173 fruits) normal fruits, followed by Treatment 2 (91 fruits) and Treatment 1 (83 fruits). On the other hand, Treatment 2 resulted 
Table 1. Effects of controlled pollination on number of female flowers, harvested fruits, normal and kopyor fruits yield of kopyor dwarf coconut in Central Java Province

\begin{tabular}{cccccccc}
\hline No. & $\begin{array}{c}\text { Controlled pollination } \\
\text { treatments }\end{array}$ & $\begin{array}{c}\text { Female } \\
\text { flowers }\end{array}$ & $\begin{array}{c}\text { Harvested } \\
\text { fruits }\end{array}$ & $\begin{array}{c}\text { Fruits } \\
\text { setting }\end{array}$ & $\begin{array}{c}\text { Normal } \\
\text { fruits }\end{array}$ & $\begin{array}{c}\text { Kopyor } \\
\text { fruits }\end{array}$ & $\begin{array}{c}\% \\
\text { kopyor }\end{array}$ \\
\hline 1. & $\begin{array}{l}\text { Bagging with pollination } \\
\text { bag, followed by } \\
\text { artificial self-pollination }\end{array}$ & 538 & 124 & 23.05 & 83 & 41 & 33.06 \\
2. & $\begin{array}{l}\text { Bagging with pollination } \\
\text { bag, followed by natural } \\
\text { pollination }\end{array}$ & 492 & 144 & 29.27 & 91 & 53 & 36.81 \\
3. & Open pollinated & 553 & 209 & 37.79 & 173 & 36 & 17.22 \\
\hline
\end{tabular}

in the highest number of total kopyor fruit yield (53 fruits; 36.81\%), followed by Treatment 1 (41 fruits; 33.06\%), and Treatment 3 (36 fruits; $17.22 \%)$. Based on this evaluation, control pollination by using isolation bag with natural pollination increased the harvested kopyor coconut fruits. Such increased may have been the results of higher possibilities of pollination of the $\mathrm{k}$ female gamete by the $\mathrm{k}$ male pollen.

Makapuno coconut, the well-known coconut mutant of the Philippines, is also controlled by a single recessive mutant gene (Ubaldo, Rillo and Cueto, 2003). According to Thampan (1981), natural fruit setting of the coconut is normally also about $30 \%$. Moreover, Maskromo et al. ( 2011) reported that there was $0-27.59 \%$ probability of harvesting kopyor yield by cross pollination among three kopyor dwarf coconut varieties in Central Java, Indonesia.

\section{Research Phase II (2012-2014)}

Preliminary results of the Research Phase II indicated that hybridization of heterozygote $K k$ kopyor coconut by homozygote $k k$ kopyor coconut resulted in the expected ratios of kopyor to normal fruit ratio (50:50\%). Three varieties of kopyor dwarf varieties were evaluated in this activities, such as: Kopyor Green Dwarf (KGD), Kopyor Brown Dwarf (KBD) and Kopyor Yellow Dwarf (KYD). Hybridization among these varieties as female parent with the homozygote $k k$ pollen donor (male parent) resulted in the same ratio of kopyor to normal fruits. The percentages of kopyor fruit yield among those three crosses ranged from $44-56 \%$. This kopyor fruit yield is higher than that of the expected natural polination $(25 \%)$. Therefore, hybridization among heterozygote $K k$ kopyor palms with homozygote $k k$ kopyor coconut can be used to increase kopyor fruit yield. Similar increased in kopyor fruit yield were observed both in Central Java and Manado, North Sulawesi.

In addition to increase in kopyor fruit yield, all of the harvested normal fruits from such $K k \mathrm{x} k k$ hybridization are expected to be all $K k$ genotype. Therefore, germination of such normal coconut fruits results in heterozygote $K k$ coconut seedlings. This is another positive point of hybridizing heterozygote $K k$ kopyor coconut palm with a homozygote $k k$ donor pollen. It produces true-to-type kopyor seedlings.

Kopyor coconut phenotype might have been controlled by single recessive gene. According to Mendel's Law of Genetics, the kopyor fruit yield was expected as many as $25 \%$ out of the harvested fruits. The single recessive gene controlling kopyor coconut phenotype may have arised through natural mutation (Toruan and Ginting, 1998).

In Makapuno coconut, the jelly-like endosperm might be due to the absence of galactomanase enzymes from the endosperm. This enzyme catalyzes the conversion of galactomanan to mannan in the coconut endosperm. In Thailand, crossing among normal dwarf and tall coconut with Kathi tall (local curd 
coconut from Thailand) resulted in Kathi hybrid capable of yielding Kathi fruits, ranged from $16.25 \%$ to $18.53 \%$ (Wattanayothin, 2010).

\section{Research Phase III (2013-2018)}

Introducing kopyor character into different genetic background of coconut will broader the existing genetic variabilities of the existing kopyor varieties. Hybridization among a heterozygote $K k$ or a homozygote $k k$ kopyor coconut varieties as the kopyor character donor with a number of elite normal coconut varieties should serve the purpose. Heterozygote $K k$ Kopyor Yellow Dwarf and Kopyor Green Dwarf were used as kopyor donor. In addition, homozygote kk Kopyor Bakauheni Tall were also used as the other kopyor donor (Figure 3).

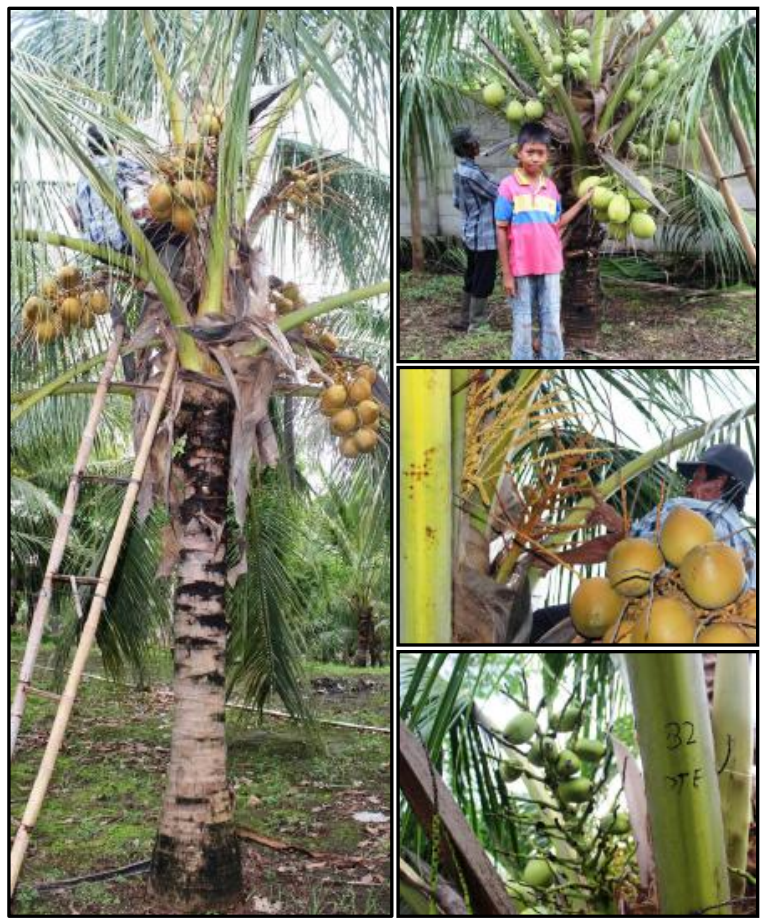

Figure 3. Materials used in research phase III. Female parents used - (A) Homozygote $k k$ Kopyor Tall Coconut and (B) Homozygote $k k$ Kopyor Dwarf Coconut. Counting pollination successes: (C) Homozygote $k k$ Kopyor Tall Coconut x Salak Green Dwarf (SGD) and (D) Homozygote $k k$ Kopyor Dwarf Coconut $\mathrm{x}$ Takome Tall (TET)
Our objectives are to combine: (1) thick and large quantity of endosperm tissue, (2) large fruit size, (3) high number of fruits per bunch, and (4) early bearing and high yield characters with the kopyor characters. These characters are originated from the following elite varieties, such as: (1) Mapanget Tall (MTT) as the donor of thick and large quantity endosperm characters, (2) Bali Tall (BIT) - as donor for large fruit size character, (3) Takome Tall (TET) - as donor for high number of fruit per bunch character, and (4) Salak Green Dwarf (SGD) - as donor for superearly bearing characters (Figure 4).
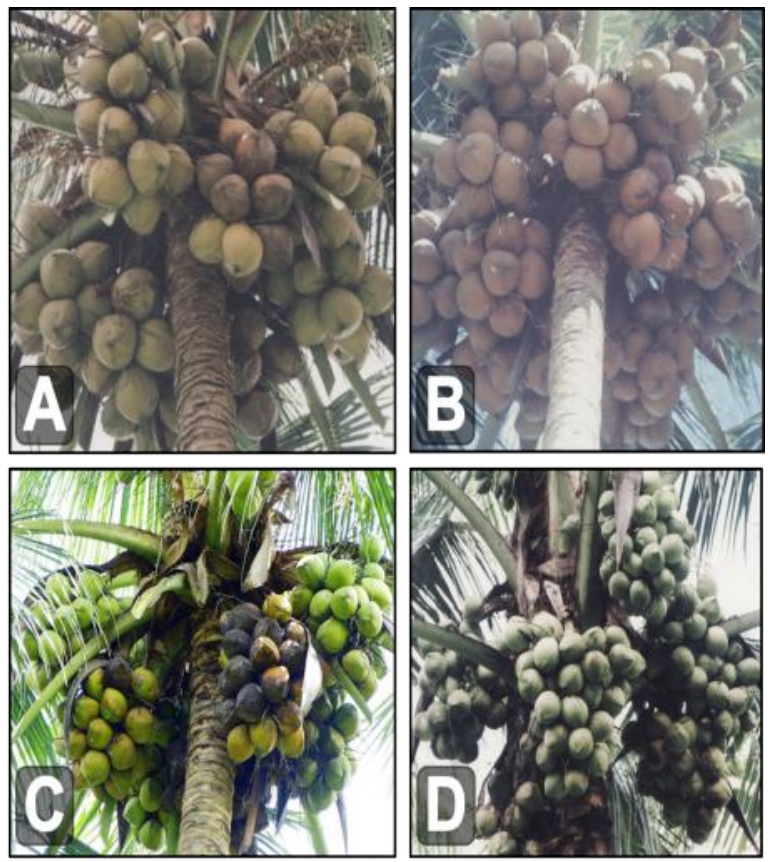

Figure 4. Normal elite coconuts used for developing breeding population. (A) BIT - Bali Tall, (B) MTT Mapanget Tall, (C) SGD - Salak Green Dwarf, and (D) TET Takome Tall coconuts

The scheme of crossing among kopyor and normal elite varieties are presented in Table 2. For each combination of hybridization, four kopyor mother palms and four elite normal male parents are used to get a total of 16 combinations of kopyor x normal coconut hybrid (Table 2). The hybridization was carried out in the mid2013 and the seednuts were harvested in mid2014. 
Table 2. Scheme of cross hybridization among kopyor coconut and normal elite varieties to generate breeding population for future kopyor coconut superior varieties in Indonesia

\begin{tabular}{|l|c|c|c|c|}
\hline \multirow{2}{*}{ Female parent } & MTT $(K K)$ & BIT $(K K)$ & TET $(K K)$ & SGD $(K K)$ \\
\cline { 2 - 5 } Dwarf type : & KGD x MTT & KGD x BIT & KGD x TET & KGD x SGD \\
\hline KGD $(K k)$ & KYD x MTT & KYD x BIT & KYD x TET & KYD x SGD \\
\hline KYD $(K k)$ & KGD x MTT & KGD x BIT & KGD x TET & KGD x SGD \\
\hline Tall type : & KBT x MTT & KBT x BIT & KBT x TET & KBT x SGD \\
\hline KGD $(k k)$ & $\begin{array}{c}\text { Kopyor and thick/full } \\
\text { endo-sperm tissue }\end{array}$ & $\begin{array}{c}\text { Kopyor and large } \\
\text { fruit size }\end{array}$ & $\begin{array}{c}\text { Kopyor and large } \\
\text { number of fruits } \\
\text { per bunch }\end{array}$ & $\begin{array}{c}\text { Kopyor and early } \\
\text { bearing, high } \\
\text { yielding }\end{array}$ \\
\hline $\begin{array}{l}\text { KBT }(k k) \\
\text { characters of } \\
\text { hybrids }\end{array}$
\end{tabular}

Note: Normal elite coconut variety MTT - Mapanget Tall, BIT - Bali Tall, TET - Takome Tall, and SGD - Salak Green Dwarf.

Progenies derived from those hybridization are expected to exhibit a high genetic diversity and can serve as the breeding population for the development of superior kopyor coconut in the future. In Thailand, improved varieties of Kathi coconut has been done by crossing with aromatic coconut (Wattanayothin, 2005). The target of this hybridization is to develop aromatic Kathi coconut (Chomchalow, 2013). Hybridization between 'Hon Nam' (aromatic) coconut variety with Kathi coconut have apparently yielded 56\% aromatic characters among the hybrid progenies (Wattanayothin, 2005).

Similar approach may be done for kopyor coconut. Previous report has indicated that kopyor character is controlled genetically (Sukendah et al., 2009), therefore, hybridization among kopyor varieties with elite normal one should combine the characters from both parents in the progenies. A number of activities are on going to evaluate the hybrids derived from the crosses. These hybrid populations are the basic foundation for kopyor coconut improvement in the future.

\section{Conclusions}

1. Control pollination of Dwarf Kopyor Coconut varieties by bagging the inflorescence increased kopyor fruit yield twice as much as those of open pollinated ones. The kopyor fruit yield reached the expected percentage of kopyor yield under the natural condition.

2. Pollinating inflorescences of farmer's kopyor coconut provenances (kopyor heterozygote $K k$ trees) using pollen harvested from zygotic embryo derived provenances (kopyor homozygote $k k$ trees) increased percentage of harvested kopyor fruit to a level of 50\% (increased from $25 \%$ of expected yield). It also produced true-to-type heterozygote $K k$ kopyor coconut seedlings $(100 \%)$, grown from harvested normal fruits (increased from a mixture 2:1 between heterozyote $K k$ kopyor and homozygote $K K$ normal seedlings).

3. Hybridization of selected heterozygote $K k$ kopyor and homozygote $k k$ kopyor coconut with elite normal coconut have been initiated and seedlings derived from 
such hybrids serve as the basis for developing new and superior kopyor coconut varieties in the future.

\section{Acknowledgement}

Part of this research were supported by the Agency for Agricultural Research and Development (AARD), Ministry of Agriculture through IPRI proposal (control pollination) coordinated by Hengky Novarianto and through "KKP3N Kopyor Coconut Project - 2013-2015" (breeding population) coordinated by Sudarsono. Funding was also obtained from Directorate of Higher Education, Ministry of Education and Culture, Republic of Indonesia through "HI-LINK Kopyor Coconut Project 2012-2014" (increasing kopyor fruit yield and production of Kopyor true-to-type seedlings) coordinated by Sudarsono. Part of this activities are used by Ismail Maskromo to write his $\mathrm{PhD}$ disertation. The authors appreciated all parties in supporting the funding of the programs and assisting executions of the activities.

\section{References}

Akuba, H.R., Mashud, N. and Miftahorracman. 2002. Identifikasi plasmanutfah kelapa potensial di Jawa Timur. Laporan Hasil Penelitian, Balai Penelitian Kelapa (Balitka), Menado, Indonesia.

Anonymous. 2004. Selayang pandang komoditi kelapa kopyor di Kabupaten Pati. Dinas Kehutanan dan Perkebunan Kabupaten Pati, Jawa Tengah.

Chomchalow, N. 2006. Maphroa Kathi. Thailand Network for Conservation and Enhancement of Landraces of Cultivated Plants (TNCEL), Bangkok, Thailand (in Thai).

Chomchalow, N. 2013. Curd coconut: Its mystery and potentialities (Review Article). Cord 29 (2): 46-51.

Mahmud, Z. 2000. Petunjuk teknis budidaya kelapa kopyor. Departemen Kehutanan dan Perkebunan. Dirjen Perkebunan. Jakarta.
Maskromo, I.; Novarianto, H.; and Sudarsono. 2011. Flowering phenology of three dwarf kopyor coconut varieties from Pati. Prosiding Seminar Nasional PERHORTI. Lembang, 23-24 Nopember 2011. pp. 1002-1010.

Maskromo, I.; Novarianto, H.; Sukma, D. and Sudarsono. 2011. Yield potential of kopyor coconut germplasm originated from Kalianda, Pati, Sumenep and Jember. Prosiding Seminar Nasional SDG local mendukung Industri Perbenihan Nasional dalam Rangka Purna Bakti staf Penganjar Pemuliaan Tanaman UNPAD dan Kongres PERIPI Komda Jabar. Bandung, 10 December 2011. pp. 499-507.

Maskromo, I.; Novarianto, H.; Sukendah; Sukma, D. and Sudarsono. 2013. Productivity of three dwarf kopyor coconut varieties from Pati, Central Java, Indonesia. Cord 29(2): 19-28.

Novarianto, H. 2013. Dwarf kopyor coconut in Indonesia. COCOINFO. 20(2): 13-15.

Novarianto, H. dan Miftahorrachman. 2000. Koleksi dan konservasi jenis-jenis kelapa unik. Makalah poster dalam Simposium Pengelolalan Plasma Nutfah dan Pemuliaan. Bandung, 22-23 September 2000. Perhimpunan Ilmu Pemuliaan Indonesia (PERIPI).

Sukendah, Volkaert, H. and Sudarsono. 2009. Isolation and analysis of DNA fragment of genes related to kopyor trait in coconut plant. Indonesian J. Biotech. 14(2): 11691178.

Thampan, P.K. 1981. Handbook on Coconut Palm. Oxford and IBH Publ. Co., Calcutta, India. $311 \mathrm{pp}$.

Toruan, N.M. dan Ginting, G. 1998. Analisis random amplified polymorphic DNA (RAPD) pada tanaman kelapa kopyor. Prosiding Konferensi Nasional Kelapa IV, 21-23 April 1998. Bandar Lampung. Puslitbangtri. Badan Litbang Kehutanan dan Perkebunan. 
Ubaldo, M.B.B.A., Rillo, E.P. and Cueto, C.A. 2003. Application of the improved embryo culture protocol for commercial production of Makapuno seedlings. Philippine J. Sci.. 132(1): 1-11.

Wattanayothin, S. 2005. The study on curd coconut hybrids. TNCEL J. 1(3):6-7 (in Thai).

Wattanayothin, S. 2010. Variety improvement of Makapuno. Proc. XLIV COCOTECH Meeting, 5-9 July 2010, Samui Island, Surat Thani, Thailand. pp. 96-108. 